Relatorio

GALICIA NO ESPAZO

CULTURAL E SIMBÓLICO

DA LUSOFONÍA

Ivo Castro

Universidade de Lisboa 



\section{INTRODUCIÓN XERAL}

\section{O portugués, do rexional ao intercontinental}

Algunhas linguas imperiais son sedentarias, outras, viandantes. As sedentarias gañaron terreo a través de sucesivas adquisicións de territorios contiguos e ocupan hoxe unha área que pode ser multinacional, pero que coincide co apoxeo do crecemento da potencia imperial. Talvez sexa o alemán, en Europa, o mellor exemplo desta asociación entre solo ininterrompido e lingua con mínimas variacións dialectais. As néboas lingüísticas xermánicas que persisten no sur de Brasil e, quizais, en Namibia son froito de fenómenos migratorios ou coloniais de pouco máis dun século e de escasa expresión numérica.

Entre as linguas viandantes están as que, na fórmula célebre de Nebrija, foron compañeiras dos imperios ultramarinos que se estableceron a partir do Renacemento: o portugués e mais o castelán xa no século XV, o inglés e o francés no XVI. O testamento de Adán, que repartía o Novo Mundo entre as coroas de Portugal e Castela, non se cumpriu con exactitude, xa que entraron na repartición outras potencias europeas que posuían portos marítimos e armadas poderosas. Os Países Baixos formaron parte desa viaxe e desa repartición, pero foron os únicos que non deixaron detrás deles territorios que falasen, de xeito sostible, a súa gutural lingua. Pareceulles máis práctico utilizar, para as relacións coas poboacións, as linguas europeas ou as versións simplificadas e rudimentarias destas -pidgins- que xa se atopasen instaladas nestes lugares: está documentado o uso que fixeron de variantes mixtas do portugués en todo o círculo que vai desde o Índico ata as Molucas.

As outras catro potencias europeas, que se apoderaron con maior ou menor firmeza de partes do mundo e as mantiveron como colonias ata que os catro ventos de cambio, na imaxe de Harold Macmillan, as transformaron en Estados 
independentes ou en neocolonias, deixaron nelas, en xeral, dous tipos de legado lingüístico -variantes máis ou menos diferenciadas da lingua europea ou linguas mixtas, como pidgins e crioulos- en función da intensidade que tivo a ocupación colonizadora en cada lugar. De aí resultaron mapas lingüísticos de escala mundial nos que o inglés, o castelán, o portugués e mais o francés, nesta orde, ocupan espazos descontinuos, diversos lingüística e culturalmente, que disputan entre si zonas de influencia -por exemplo o castelán nos Estados Unidos- e que, no seu seo, é dicir, entre as variantes da mesma lingua que en cada un dos Estados ex-coloniais serven de lingua nacional maioritaria, vehicular ou aglutinadora, establecen relacións de convivencia e de mutuo entendemento non sempre fáciles de levar. A noción de francofonía provén dun proxecto unificador do espazo lingüístico francés cunha vocación tan ordenada e centralizada como os xardíns do palacio de Versalles. Pola contra, a práctica seguida nos países de lingua inglesa foi a do liberalismo económico: a decisión e a última palabra correspóndenlle ao mercado e este apunta no sentido dunha progresiva autonomía das variantes nacionais da lingua, o que leva a concibir o inglés como unha futura familia de linguas e permite que autores como Tom McArthur escriban libros con títulos como The English Languages (Cambridge, 1998).

O portugués, como é sabido, flutúa entre os modelos unificador e separador. A esta cuestión dedicareille a parte final da miña exposición. Pero antes tratemos brevemente o modo en que o portugués se construíu como lingua viandante. Evidentemente, o portugués non naceu asemade en todo o enorme conxunto de territorios que ocupa hoxe en día, senón nun pequeno recanto do noroeste da Península Ibérica, mostrando sen dúbida tendencias de expansión cara ao sur. Naceu naquilo que Joseph Piel chamaba a Galecia Magna, denominación que abranguía a actual Galicia, o norte de Portugal e un pouco de Asturias. Non naceu, como pensaban Alexandre Herculano e Leite de Vasconcelos, no centro de Portugal; non é unha lingua que descende do latín dos lusitanos, senón dos galegos. Por iso, é xusto darlle como berce simbólico Santiago de Compostela, aínda que fose máis largo e diferenciado o espazo en que dúas consoantes dentais, [l] e [n], se mostraron particularmente débiles en posición intervocálica e sufriron síncope; ao tratarse de dous sons moi frecuentes, un gran número de vocábulos víronse afectados por esa síncope, que tivo consecuencias colaterais nos encontros vocálicos, na estrutura silábica e nas distincións morfolóxicas. 
Estes fenómenos, unidos a outros de base fonolóxica, foron suficientes para condicionar a evolución futura do romance do noroeste peninsular, ao cal contribuíron a distinguir dos romances do centro e do sur da Península Ibérica.

Aínda hoxe é perceptible na paisaxe portuguesa a fronteira entre a Galecia Magna e as terras centro-meridionais. Se imos pola estrada de Lisboa cara ao norte, xusto ao pasar Coimbra hai un punto en que comezamos a atopar casas de chan de terra e primeiro andar, coa división do gando embaixo e as persoas vivindo encima. Case de súpeto, a viña pasa a estar pendurada de arcos ou nas pólas das árbores, a «viña de enforcado» que produce o «viño verde» portugués. A carón das casas descubrimos unhas peculiares construcións sobre estacas, para almacenar cereais: son os hórreos, de madeira na Beira Litoral, mais cara ao norte de granito ou, modernamente, de cemento. Cando vemos estes sinais de ocupación humana, decatámonos de que o territorio xa é distinto, máis antigo. Entramos na área de orixe da lingua portuguesa, un territorio que se estende ininterrompidamente desde A Coruña, no extremo setentrional de Galicia, ata o val do río Vouga, paralelo a Aveiro, un territorio cuxa poboación nativa, galega ou portuguesa, fala a lingua que sempre usaron aí os seus devanceiros. Algo do que un lisboeta non se pode compracer. Un lisboeta nativo, descendente de moitas xeracións de habitantes da cidade ou do sur, fala unha lingua autóctona, que foi transplantada da Galecia Magna. Exactamente do mesmo xeito en que a lingua falada en Río de Xaneiro ou en Maputo houbo de chegar a estes lugares a través das augas do Atlántico sur e mais do Índico.

O primeiro desprazamento en dirección ao sur foi aquel transplante inicial da lingua do norte, onde se encontran as orixes do Reino de Portugal, cara ao resto do territorio, onde o galego-portugués se superpuxo ao árabe.

O segundo desprazamento, tamén cara ao sur, consistiu nun enorme salto fóra de Europa. Compañeira dos Descubrimentos, a lingua instalouse en illas atlánticas deshabitadas -Madeira, Azores, Cabo Verde, San Tomé, Príncipe, Fernando Pó- e no litoral africano situado fronte a estas. Despois de virar para o leste no extremo sur de África, no cabo chamado Tormentoso, e máis tarde da Esperanza, Portugal instálase en puntos do litoral asiático que lles servían de soporte ás rutas marítimas, facendo o mesmo, despois, no litoral brasileiro. Se ata daquela a lingua nunca perdera de vista o mar, non ocorreu isto en Brasil. Aquí vemos como os portugueses van cara ao interior nos séculos XVI e XVII, 
cousa que en África non fixeron ata o XIX, cando houbo unha penetración considerable de colonos portugueses cara ao interior de Angola e Mozambique. Non tiveron tempo de tentar isto no Oriente, onde o dominio militar pasou pronto a mans inglesas e holandesas.

Estes dous movementos sucesivos de desprazamento territorial da lingua portuguesa definiron na súa historia dous ciclos cronolóxicos continuos, separados por unha cesura: o ciclo de "elaboración da lingua»; o galego-portugués trasládase ao sur e transfórmase e convértese na base dunha norma culta de características meridionais que sería considerada lingua nacional; namentres, no norte a lingua medieval tórnase dialectal e conserva ata hoxe características como a africada [t] ] ou o tratamento de «vós», plural de «ti», igual ao que existía en Roma. O segundo gran ciclo é o da «expansión da lingua»; o período que vai do século XV ata o comezo do XVI é aquel en que a lingua se transfigura máis radicalmente. As transformacións na lingua falada e mesmo tamén na escrita son moitas e simultáneas. Mentres que se reestrutura e consolida dentro, a súa expansión fóra de Europa fai necesario distinguir entre portugués europeo e portugués extraeuropeo.

No europeo, o léxico enriquécese a través do contacto con linguas exóticas, pola importación de cultismos latinos e gregos e pola adopción do castelán como segunda lingua literaria. Convértese no patrón nacional, descrito polos gramáticos do século XVI e seguintes. Os dialectos distribúense segundo un mapa moi semellante ao moderno, cun norte conservador e un centro e sur que comprende as terras reconquistadas, máis uniforme e modernizado. $\mathrm{O}$ son do portugués europeo non sufriu, a partir do XVIII, alteracións significativas.

No tocante ao portugués extraeuropeo, cómpre distinguir os dous tipos específicos de actuación lingüística xa mencionados: por unha banda, o transplante directo de dialectos portugueses, con evolucións propias, a vastos territorios como Brasil, Angola, Mozambique e tamén as colonias de emigrantes de Europa e América; pola outra, a fusión con linguas locais, ao longo do litoral africano e asiático, para producir pidgins e crioulos, posiblemente cunha matriz única -o protocrioulo portugués-, o que explica as semellanzas entre linguas que nunca estiveron en contacto. Os resultados modernos deste proceso son as situacións lingüísticas de Cabo Verde, Guinea-Bissau, San Tomé e de certas zonas do Índico e Oceanía. 
Unha visión sumamente eurocéntrica do portugués, que non defendo pero que subsiste en moitos subconscientes, non pode deixar de recoñecer no espazo internacional da lingua portuguesa tres círculos concéntricos, nos que esta vive en condicións cada vez máis afastadas da variante europea:

O círculo máis próximo é o da emigración, que en realidade comprende unha «emigración de longo percorrido», constituída por comunidades que deixaron Portugal hai moito tempo para marcharen moi lonxe, e cuxas novas xeracións están plenamente integradas na cultura das sociedades en que viven e que contan con coñecementos residuais do portugués, alimentados máis polos estereotipos dos pais e os avós que polo contacto regular e actual con Portugal. Xunto a esta «emigración de longo percorrido» aparece unha «emigración costeira», de carácter menos definitivo posto que se dirixiu a países europeos dos que é fácil volver a Portugal.

O segundo círculo está constituído polas comunidades que falan portugués nos países de descolonización recente. É unha boa nova comprobar que, en países como Angola e Mozambique, a poboación que aprende o portugués como lingua materna está a medrar moi rapidamente, malia que a causa deste fenómeno sexa a concentración, arredor das respectivas capitais, de masas de refuxiados que falan outras linguas e que só poden empregar o portugués como lingua vehicular. En Mozambique, nun período de dezasete anos, é dicir, a vida dun adolescente, a poboación que fala portugués como lingua materna creceu do 1 ao $6 \%$, e a que o fala como segunda lingua pasou do 25 ao $33 \%$, proporcións que talvez sexan aínda máis elevadas na actualidade angolana, ata o de agora menos estudada.

Finalmente, o terceiro círculo é o brasileiro. En Brasil o portugués é a lingua materna universal, con normas propias que non se rexen, hoxe, polo modelo europeo. Brasil compartiu con Portugal os últimos cincocentos anos da lingua común e, en certos aspectos, conservouna mellor que os portugueses: construcións sintácticas que moitos consideran innovacións brasileiras xa estaban no código xenético da lingua medieval e foron abandonadas polos portugueses, pero non polos brasileiros; Camões, ao falar, quizais soase tan brasileiro coma lisboeta. Nos confíns de Mato Grosso aínda se oe a mesma africada [t $[$ ] que, en Trás-os-Montes, ao principio da palabra «chuva» e do verbo "chamar»; esa antiquísima consoante xa ocupou o espazo da lingua portuguesa na súa totalidade, 
malia que hoxe, como reliquia que é, perdura apenas nas franxas máis remotas e opostas. Todo isto significa que non lle pertence a Portugal o privilexio da historia, como tampouco lles pertence a Brasil ou a África a exclusividade da innovación e da modernidade.

No ano 2000, o portugués era a lingua materna de, polo menos, cento oitenta millóns de persoas repartidas por todos os continentes, e a lingua oficial de sete Estados, aos que se lles engadiu pouco despois Timor-Leste. Por estas razóns, é unha lingua multinacional, vehículo de comunicación entre cidadáns de Estados que a teñen como oficial; e é tamén unha lingua internacional, pois serve de porta de entrada, como segunda lingua, para os falantes nativos doutras.

Esta condición multinacional, unida á dispersión xeográfica, tivo e continúa a ter importantes reflexos na unidade da lingua. As condicións de xeografía, sociedade e comunicación permiten afirmar que no futuro se producirá a fragmentación do seu sistema lingüístico. A construción e normalización das distintas variantes nacionais poderán ser os primeiros pasos neste sentido. $\mathrm{Ou}$ mellor dito, poderán ser longas andaduras constituídas por incontables pequenos pasos sen a conciencia de a onde se dirixen.

No nivel das actitudes conscientes, o tema da unidade da lingua motivou, durante o século XX, a aparición de dous modos típicos e claramente distanciados de reacción: unha "pulsión unificadora» e unha "pulsión separadora». A primeira atinxiu o seu cénit co acordo ortográfico luso-brasileiro de 1945, que aspiraba a reunificar, a través dunha ortografía común, as variantes nacionais en todas as súas manifestacións, incluídas as léxicas, sintácticas e fonolóxicas. E proseguiu con novas tentativas ortográficas nos anos oitenta, revelándose hoxe como substrato do concepto de lusofonía e como xustificación de organizacións políticas como a Comunidade dos Países de Lingua Portuguesa e o Instituto Internacional da Lingua Portuguesa, cuxas modestas iniciativas apuntan cara ao éxito da "pulsión separadora». Esta, pola súa parte, tivo o seu cénit na recusa brasileira a adherirse ao acordo de 1945, manténdose así o campo dividido entre dous códigos ortográficos: un privativo do Brasil e outro común a Portugal e ás súas antigas colonias. Na actualidade, a "pulsión separadora» destaca entre as preocupacións de moitos lingüistas, non só brasileiros, senón tamén portugueses e africanos, os cales argumentan que a sepa- 
ración de placas tectónicas que está en marcha no espazo portugués xa superou a variación entre normas da mesma lingua e se configura como a creación de gramáticas distintas, o que equivale, en linguaxe técnica, a falar de novas linguas.

Este conflito entre pulsións foi explicado de forma exemplar por Eduardo Lourenço en $A$ Nau de Ícaro: por un lado, portugueses e brasileiros «nunca formarán un conxunto, no sentido dunha comunidade lingüístico-cultural»; por outro, para uns e para os outros -e tamén para os africanos-, a lingua portuguesa constitúe o «único elo ineludible». Conciliar estas posturas contrapostas parece ser o noso destino e, esperemos, o noso talento.

\section{LUSOFONÍA}

\section{Crítica do concepto}

A condición internacional da lingua portuguesa viviuse, ao longo dos tempos, de dous modos típicos e claramente distanciados, que chamarei "pulsión unificadora» e "pulsión separadora». Non se trata de explicar aquí a historia e a crítica destas dúas forzas, reaccións opostas - unha inconformista, outra insaciableperante o fenómeno constatado da internacionalidade da lingua; limitareime a esbozar a súa caracterización.

A "pulsión unificadora» foi exemplarmente explicada por Manuel de Paiva Boléo (1968, p. 9) no discurso de apertura dun simposio luso-brasileiro celebrado en Coimbra en 1967, cando os parceiros recoñecidos eran aínda portugueses e brasileiros unicamente. Antes dalgunhas tarefas urxentes, como a unificación da nomenclatura gramatical ou o acordo ortográfico, era prioritaria, na opinión do profesor de Coimbra, a tarefa «de se criar nos portugueses e brasileiros uma mentalidade e uma consciência de unidade de língua em que sejam aceites, dentro da norma culta, certas divergências de pronúncia, de léxico e, embora em menor escala, de construção sintáctica, divergências essas que não afectam a mencionada unidade idiomática».

Como é sabido, poderían aliñarse xunto a esta declaración outras de lingüistas brasileiros totalmente concordantes con ela. 
A "pulsión separadora», como é natural, ten orixe brasileira e manifestouse especialmente na literatura, desde o Romanticismo ata o Modernismo; na actualidade, é apoiada polas observacións de moitos lingüistas non só brasileiros, senón tamén portugueses e, porque o asunto tamén lles atangue, africanos. Gustaríame engadir que estas dúas pulsións non se consideran provenientes de actitudes nacionais, e moito menos nacionalistas.

A «pulsión unificadora», que constituíu a matriz doutrinaria do acordo ortográfico de 1945, que inspirou as propostas de Boléo en 1967 e que se manifestou de novo no abortado proxecto de acordo ortográfico de 1986 -pero recuou nos seguintes proxectos-, está hoxe plenamente activa a través da idea da lusofonía. Como desexo ser ecuánime, hei de recoñecer que existe unha certa utilidade terminolóxica no substantivo "lusofonía», que vén moi ben cando se pretende designar con brevidade «o grupo dos sete Estados de lingua oficial portuguesa». O termo «países lusófonos» é aínda máis conveniente cando se desexa identificar os países africanos sen recorrer á sigla PALOP, de melindrosa flexión plural, ou á xurídica forma «ex-colonias», con respecto á cal ten vantaxes eufemísticas.

Sería sumamente fácil argumentar que o concepto de lusofonía é neocolonialista. É certo que o seu hábitat máis favorable semella ser Portugal, onde aparece constantemente na prensa, nos debates e mesmo nos nomes de entidades públicas: escríbense libros e organízanse coloquios para debater sobre a lusofonía, unha universidade privada chámase Lusófona, etc. O debate de sempre entre Portugal como nación con vocación europea ou como nación con vocación transcontinental tamén axuda, aínda que por motivos contrarios. Tanto os nostálxicos do Imperio coma os europeístas recoñecen as vantaxes de que Portugal manteña unha posición privilexiada no diálogo entre os países do norte e mais do sur. Pero convén non esquecer, xa que os acontecementos son recentes, a implicación e o empeño de políticos e intelectuais brasileiros na invención da lusofonía, promovendo a fundación de institucións concibidas para crear e poñer en circulación esta nova idea, como é o caso do chamado Instituto de S. Luís do Maranhão, da actual CPLP e do frecuentemente mencionado Instituto Internacional da Língua Portuguesa, institucións cuxa evolución obedece a un paradigma de fracaso.

$\mathrm{Na}$ súa versión maximalista, non coñezo mellor definición deste concepto que a da socióloga Maria Beatriz Rocha Trindade (1998, p. 43). Para ela, a lusofonía: 
...compreende os falantes da língua, seja ela materna, oficial ou estrangeira; os espaços onde se situam e, por extensão, os eventualmente não lusófonos que os habitem; os países soberanos onde essa língua é predominante e, bem assim, as comunidades minoritárias que se reclamam do Português, ou da correspondente cultura, ou de uma ancestralidade, conhecida ou simplesmente provável, que com Portugal esteja relacionada.

Non analizarei o ecumenismo desta concepción de lusofonía. Só me interesa sinalar que está lonxe de ser apoiada universalmente entre os portugueses. Ante todo, é sintomático que un historiador como José Mattoso puidese escribir un libro titulado $A$ Identidade Nacional (Lisboa, 1998) sen sentir a necesidade de facer alusión ningunha ao concepto de lusofonía. A drástica forma de reticencia que é o silencio explícase, no caso de Mattoso e de moitos historiadores modernos portugueses, pola visión de Portugal como país europeo cuxa expansión extraeuropea e as consecuencias desta non son factores esenciais para o entendemento da nación. Véxase, se non, o reducido tratamento dos Descubrimentos e da época colonial na obra História de Portugal, que Mattoso coordinou.

Hai pouco referinme aos creadores de opinión. Hoxe en día, poucos son máis respectados en Portugal que Eduardo Lourenço (1999, p. 174), que define a lusofonía como:

...esfera de comunicação e compreensão determinada pelo uso da língua portuguesa com a genealogia que a distingue entre outras línguas românicas e a memória cultural que, consciente ou inconscientemente, a ela se vincula. Nesse sentido, é um continente imaterial disperso pelos vários continentes onde a língua [dos escritores] se perpetuou essencialmente a mesma, para lhe chamarmos ainda portuguesa, e outra na modulação que o contacto com novas áreas linguísticas lhe imprimiu ao longo dos séculos.

Esta definición parece subscrita por un lusofonista fervoroso. De feito, non cuestiona o papel da lingua portuguesa como vehículo de comunicación transcontinental, intacta na súa esencia malia as moitas mudanzas locais. O que, na visión de Eduardo Lourenço (1999, p. 136-137), compromete o funcionamento da lusofonía non é o escenario, senón que son os actores que alí se moven. Máis concretamente, son os discursos culturais de cada un dos países sobre os demais o que lle merece páxinas severas e distribuídas equitativamente: 
O discurso cultural brasileiro [...] exprime e faz corpo não só com a pulsão grandiosa e mítica que atravessa a actual realidade brasileira e condiciona as suas perspectivas hegemónicas em todos os domínios, mas também com essa rasura, já antiga, da raiz lusitana donde procede. Mas esse discurso, com o seu ressentimento latente [...], não é nada como o discurso português sobre o Brasil, discurso onírico e criador do permanente quid pro quo das nossas relações com a famosa cultura brasileira a que chamamos irmã por não ousarmos chamar-lhe filial. O discurso português sobre o Brasil, tal como uma longa tradição retórica e historiográfica recita e reescreve sem cessar, é uma pura alucinação nossa, que o Brasil -pelo menos desde há um século- nem ouve nem entende.

Todo isto, razoa Eduardo Lourenço (1999, p. 159), «forma parte da orde natural das cousas [...], não é un drama, senão un afastamento de feito». Por iso, conclúe que os portugueses e mais os brasileiros «nunca formaremos um conjunto, no sentido de comunidade linguístico-cultural -nem mesmo acrescentando o contributo dos novos países africanos de expressão portuguesacapaz de constituir um pólo de influência histórico-política no mundo, como indubitavelmente será o caso dos países de expressão hispânica».

Cando en Brasil, Portugal ou en África respectados intelectuais se pronuncian deste xeito, cómpre preguntármonos que auxilio lle cabe agardar aínda á «pulsión unificadora» dos nosos pobos. Pero eses críticos ofrecen unha resposta sorprendente: cuestionan a lusofonía desde diversos puntos de vista, xeoestratéxicos, culturais, históricos, pero aceptan que esta ten polo menos un fundamento indiscutible; constitúe, nas palabras de Eduardo Lourenço (1999, p. 171), «uma comunidade que tem como único elo incontornável a língua». Isto dálle unha importancia considerable ao que os lingüistas teñan que dicir sobre este asunto.

\section{Galicia na lusofonía}

Non me parece que o modelo da francofonía sexa o máis interesante para a situación do portugués, aínda que obviamente a palabra "lusofonía» se calcase de «francofonía». O modelo inglés parece ser o máis interesante porque o que vemos, ollando para a comunidade dos países de lingua oficial portuguesa, é que tamén hai unha polarización entre, por unha banda, Brasil, e, pola outra, Portugal e os países africanos. Por un lado, os países africanos lingüística e cul- 
turalmente máis próximos a Portugal, e, polo outro, Brasil. Esta análise implica, unha vez máis, que aceptemos que a lusofonía non é unha entidade homoxénea: ten divisións internas, que pasaremos a expoñer.

A bipolarización entre Portugal e Brasil podería dar para toda unha tarde de conversa, con axustes de contas, queixas, recriminacións: no fondo, é unha historia de amor insatisfeita. Unha historia digna da nosa poesía trobadoresca, na que sempre hai quen está ausente, ou está a ollar cara a fóra, ou a marchar, etc. Con todo, reprimindo a tentación de ir por ese lado e volvendo á situación actual, diría que esta historia está integrada por compoñentes desequilibrados: por un lado, un país como Brasil, que é un país novo, cheo de futuro, con potencial humano e unha riqueza para definir os seus modos de vida futuros sen necesidade de constrinximentos alleos, de quedar atado a alianzas, a restricións vindas de fóra. É un país que, seguindo os ventos da Historia, está a ollar cara ao Pacífico, cara aos Estados Unidos, e é normal que así sexa. É un país que está a seguir en boa medida os modelos estadounidenses e que, se tivese un boom económico acompañado dun cambio social considerable que acabe co afastamento entre a elite e a enorme masa desfavorecida, se conseguise resolver isto, será unha gran potencia. E nós, os portugueses, non temos máis que congratulármonos por iso. Pero xa pasou o tempo do «Portugal, meu avoíño». Algúns brasileiros non saben que Portugal existe. E por que habían de sabelo? Por que un descendente de xaponeses ou de italianos que vive nunha zona onde non está en contacto coa colonia portuguesa ha de saber que Portugal existe? Brasil non ten, nin lle é esixible que teña, un coñecemento perfecto, actualizado e desmitificado de Portugal. Portugal, en cambio, talvez teña un maior coñecemento de Brasil, aínda que condicionado por prexuízos. En moitos portugueses hai desdén en relación con Brasil, existe a vella idea de que os brasileiros non falan a nosa lingua como é debido, cando, non está de máis lembralo, desde o punto de vista fonético, as vogais deles son as vogais de Camões. Nós fomos os que cambiamos.

Polo tanto, hai algúns malentendidos entre Brasil e Portugal que haberían de actualizarse, e outros que teriamos que evitar. Toda a cuestión ortográfica debeu de evitarse. Non levou a nada, só a darnos a moitos a oportunidade de dicirmos o que nos vén á cabeza sen pensar, cousas desagradables sobre Brasil. Cando, desde logo, había cousas máis interesantes que Portugal e Brasil podían facer que 
un acordo ortográfico problemático. Non se dá creado un Instituto de Terminoloxía luso-brasileiro que garanta que os novos produtos, os novos conceptos técnicos e científicos, reciban a mesma designación no portugués de Portugal e de Brasil. É dicir, que a produción de neoloxismos se faga dun xeito harmonioso e negociado entre os dous países.

Esta cuestión de Brasil versus Portugal, esencial para aceptar ou non a existencia dunha homoxeneidade lusófona, resolveríase facilmente a prol da lusofonía se todo o mundo estivese de acordo en que a lingua é a mesma nos dous países. En situacións como estas, é frecuente preguntarlles aos expertos o que opinan. Como é típico dos lingüistas, ou mellor dito, dos especialistas, non concordan entre eles. Hai unha postura moderadamente conservadora, tanto en Brasil como en Portugal, cuxa formulación máis afortunada, por menos apaixonada, é a de Celso Cunha. Esta formulación consta, por exemplo, na Nova Gramática do Português Contemporâneo, que escribiu con Lindley Cintra, e en moitas outras obras, especialmente en Política e Cultura do Idioma, de 1979. Afirma que en Portugal e Brasil hai unha soa lingua, un sistema lingüístico cunha forte variación dialectal interna -unha variante propia de Portugal, outra propia de Brasil-, correspondendo a esa variación, en cada un dos Estados, unha variante culta nacional, unha especie de estándar. As dúas variantes cultas nacionais, a brasileira e mais a portuguesa, teñen un status equivalente, pero non se confunden. Non se manifestan só na oralidade, senón tamén na escrita. Estas variantes nacionais son, por dicilo así, a forma en que as clases cultas, alfabetizadas e educadas se expresan nos dous países, quer en situacións coloquiais, quer na escrita, literaria ou non. A nivel nacional, estas teñen, xa que logo, un papel unificador, porque se manifestan, con maior ou menor intensidade, no discurso de calquera falante culto do país, con independencia de cal sexa o seu dialecto materno. Por outra banda, ambas as dúas encádranse dentro dun único sistema lingüístico portugués que, este si, é común aos dous países. Esta formulación do problema ten a vantaxe de que desbota a idea de que unha variante nacional poida ser superior, máis culta, máis perfecta que a outra. Concretamente, non apoia o presuposto de que un brasileiro falará mellor canto máis se aproxime ao modelo do portugués europeo.

Esta descrición é facilmente extensible a África, co matiz de que neste momento non se observa en país africano ningún unha variante nacional pro- 
pia, pero é de esperar que, co tempo, se desenvolva nalgúns países, polo menos, esa variante nacional.

Nesta corrente de pensamento cómpre recordar a contribución de Lindley Cintra, que engadiu outra variante nacional: a galega. Para el, a forma de compatibilizar as relacións do galego moderno co portugués era considerar que o sistema lingüístico é o mesmo e que en Galicia se está a desenvolver unha variante nacional. É certo que tal idea non lles agrada moito aos galegos, uns porque cren que non é suficiente e outros porque consideran que resulta excesivo. Como é sabido, en Galicia existen dúas correntes de opinión en relación coa súa propia lingua: unha é a que considera que o galego é unha lingua románica, autónoma con respecto ao castelán e tamén ao portugués. Outra corrente, moito menos numerosa pero bastante máis vocal, di que o galego moderno, como o medieval, forma parte do sistema do portugués e debe subordinarse á variante culta portuguesa. Nótese que esta proposta é bastante máis integradora que a de Lindley Cintra; os seus defensores son os únicos cidadáns que coñezo que aplican as normas do Novo Acordo Ortográfico, que non aplica ninguén máis. $\mathrm{Na}$ miña opinión, é difícil defender o mantemento da unidade entre o galego e o portugués como se ela nunca deixase de existir, xa que hai un feito histórico que non se pode pasar por alto: no século XV a clase dirixente galega, do clero e da nobreza, foi erradicada de Galicia e substituída por xerarquías castelás. Cando Nebrija dicía que «a lingua é a compañeira do Imperio», talvez pensase no Novo Mundo, pero a realidade é que esta máxima se aplicaba tamén ao interior da Península Ibérica, onde o Imperio castelán se estaba a asentar en Galicia e en Cataluña e impoñía a súa lingua como arma imperial. Aínda neste século, pouco antes do franquismo, os nenos galegos que usasen a súa lingua materna nas escolas primarias eran castigados porque «non falaban a lingua do Imperio». O caso do galego, despois desta decapitación medieval, foi por desgraza o dunha lingua que queda reducida a un uso minoritario, só como lingua oral. Quen escribise tiña que facelo en castelán, quen quixese falar no rexistro culto tiña que utilizar o castelán. O galego quedou illado e apenas nos últimos cen anos é que foi rexurdindo, e moi ben, como unha literatura puxante, que nada ten que ver coas solucións portuguesas. Pretender reaproximar o galego e mais o portugués neste momento, á parte das aproximacións lexítimas entre dúas linguas sumamente semellantes, que permiten a intercomunicación oral e 
que gozan de contigüidade territorial, pode supoñer camiñar en sentido contrario á Historia. E este non é, ademais, un problema en que os portugueses deban intervir.

Pero volvamos á cuestión das relacións lingüísticas entre Portugal e Brasil. Xa vimos que a opinión dos lingüistas conservadores é que o portugués constitúe un sistema único, con dúas variantes nacionais. Con todo, tanto en Brasil como en Portugal existen grupos importantes de lingüistas que practican disciplinas modernas, como a Sociolingüística e a Lingüística teórica, e que non están de acordo con isto. Pola contra, afirman que entre Portugal e Brasil as diferenzas de estrutura lingüística están tan avanzadas que xa se pode falar de dúas linguas con gramáticas diferentes. E o acento ponse na «Gramática». Neste sentido, se as estruturas gramaticais de base son diferentes, a lingua non é a mesma. Aínda que exista comprensión mutua, para o que abonda con que a fonoloxía e o léxico non sexan moi diferentes, se as estruturas de base están suficientemente distanciadas, daquela a lingua, entendida no sentido que os lingüísticas lle dan, non é a mesma. Este distanciamento vén de lonxe. Cando lemos certos manuais escolares de finais do século XVIII, feitos en Brasil, vemos que os mestres se preocupan por corrixir erros que non son máis que marcas constantes da fala brasileira de hoxe. Así e todo, na actualidade, alén das evidentes diferenzas que existen no léxico -xa fixen referencia, por exemplo, á terminoloxía científica e técnica, que está completamente divorciada en ambos os dous países- e das fonolóxicas, nos últimos anos atendeuse moito a aspectos da morfoloxía e da sintaxe. Aí é onde máis afecta, porque aí é que estamos a falar realmente dos alicerces dun sistema lingüístico. Só vou dar dous exemplos. Un deles é ben coñecido por todos. $\mathrm{Na}$ lingua portuguesa de Portugal úsanse os pronomes persoais de terceira persoa na forma átona -Eu conheci-o-, mentres que no brasileiro se usa o pronome tónico -Eu conheci ele-. Cuestións como estas son irreversibles. Pero hai outras diferenzas sintácticas, como esta estudada por Inês Duarte e Isabel Faria: un brasileiro culto acepta unha frase como «Esse carro furou o pneu» ou «Esse rádio estragou o ponteiro». Un portugués dirá «O pneu do carro furou-se» ou "O ponteiro do rádio estragou-se». Pois ben, este contraste na aceptación de frases por parte de falantes da variante culta de ambos os dous lados permite que a tipoloxía lingüística clasifique o portugués de Brasil como unha lingua con preeminencia do tópico - «esse rádio» ou «esse pneu» non son os suxeitos da acción, 
senón o que é máis importante, o que se denomina un tópico-, mentres que o portugués de Portugal continúa a ser unha lingua con preeminencia do suxeito. Isto é un tipo de diferenza estrutural moi profunda e resulta, evidentemente, irreversible. Non existe escola ningunha que consiga inverter isto.

\section{FORZAS CENTRÍPETAS E CENTRÍFUGAS}

Non sorprende a conclusión á que chega Nicholas Ostler nun libro publicado recentemente (2006, p. 315): a importancia actual da lingua portuguesa, a escala mundial, débese máis ao desenvolvemento económico e demográfico de Brasil que á expansión portuguesa. O que lle formula un dilema interesante a Portugal: apostar pola unidade dunha lingua impulsada a partir de Brasil ou preservar a súa autonomía e especificidade nun marco de desintegración do sistema lingüístico.

Están en movemento, hai bastante tempo, forzas que buscan, máis ou menos conscientemente, promover unha ou outra das alternativas que este dilema ofrece. Como dixemos antes, poden identificarse, a través de manifestacións de variada natureza, dous modos típicos e claramente distanciados de reacción: unha "pulsión unificadora» e unha "pulsión separadora", que se enfrontan no espazo da lingua portuguesa.

\section{Portugal}

Polémica ortográfica e xenofobia.

\section{Brasil}

Ensimesmamento da opinión pública. Nacionalismo e antieuropeísmo nas posturas dos lingüistas.

\section{África}

Mozambique é o país africano cuxa situación lingüística é mellor coñecida grazas ás estatísticas nacionais e ao seguimento de lingüistas. No tocante ao xogo 
entre forzas centrípetas e centrífugas, Mozambique ofrece evidencias interesantes en ambos os dous sentidos, polo que parece que o problema de resolución máis urxente é a falta dunha norma culta ( $O$ Portugués de Mozambique, esbozo, Newsletter Instituto Camōes, número 123, 12 de marzo de 2008, Suplemento do $J L$ número 977 , ano XXVIII).

No ano 2008 deberían obterse os datos preliminares sobre o panorama da evolución da difusión da lingua portuguesa en Mozambique, de acordo cos resultados do III Censo Xeral da Poboación e das Vivendas, realizado entre o 1 e o 15 de agosto de 2007, dez anos despois de que o II Censo mostrase un avance significativo na difusión do portugués naquel país da costa oriental de África.

Desde 1980, ano do I Censo, ata 1997, o número de falantes de lingua portuguesa pasou do 25 ao 39\%, nun país que estivo en guerra entre 1977 e 1992, cando neste último ano foi asinado o Acordo de Paz de Roma entre o goberno do Partido Frelimo e o movemento guerrilleiro da Renamo.

En 1980, a porcentaxe dos que tiñan o portugués como lingua materna non superaba o 1,2\%. Pasados dezasete anos, xa representaban o $6 \%$ da poboación.

No momento da independencia, en 1975, os falantes de portugués non chegaban ao $10 \%$ da poboación mozambicana, porcentaxe que subiría exponencialmente coas políticas de escolarización exclusiva en portugués e de alfabetización, que tiveron un gran dinamismo nos primeiros anos de vida do novo Estado.

Esta política foi o resultado da decisión de converter en constitucionalmente oficial a lingua portuguesa, «dada a historia do seu uso en Mozambique, o tipo de diversidade lingüística predominante no país, as premisas ideolóxicas relacionadas co tipo de sociedade concibida para o país», segundo Gregório Firmino, profesor da Universidade Eduardo Mondlane (UEM) e autor do estudo de referencia do INE mozambicano sobre os datos do censo de 1997, titulado Situação Linguística de Moçambique (2000).

A lingua materna da esmagadora maioría da poboación é do grupo bantú (93\%), pero esta pertenza común non impide que aos mozambicanos lles resulte $\tan$ difícil entenderse entre si nas linguas nacionais como aos falantes do grupo de linguas indoeuropeas ás que pertence o portugués.

Este é un país que, segundo Armando Jorge Lopes, actual director da Facultade de Letras e Ciencias Sociais da UEM, presenta unha "gran diversidade lin- 
güística» porque menos do $50 \%$ da poboación fala a mesma lingua, unha situación que se dá en vinte e cinco dos cincuenta e oito países africanos. O censo de 1997 mostra que as cinco linguas nacionais usadas con máis frecuencia -emakhuwa, xichangana, elomwe, cisena e echuwabo- representan o $58 \%$ da poboación, e as dúas primeiras apenas superaban o 10\%. Engade que varias linguas nacionais de Mozambique teñen importantes comunidades de falantes en países limítrofes, agás a principal delas, o emakhuwa, falado na metade norte do país.

Esta situación fixo necesaria a adopción do portugués, xa extensamente usado entre as elites dirixentes independentistas, como lingua franca oficial e de «unidade nacional». A lingua portuguesa foi considerada polo Estado mozambicano como un instrumento para favorecer o proceso de unidade nacional, creando unha identidade mozambicana.

Cabería esperar que este proceso «mozambicanase» a lingua oficial, como se indica nun documento gobernamental sobre a política lingüística, de 1983, no que se defendía a «mozambicanización» do portugués falado en Mozambique «na súa estrutura, no seu léxico, na súa pronuncia, no seu ritmo, na súa musicalidade».

Con todo, segundo sinala Perpétua Gonçalves, profesora da UEM, cando a «nativización» do portugués foi alén da innovación léxica e da pronuncia «africanizada» para entrar nas frecuentes innovacións gramaticais, as elites, que tiñan en mente o modelo brasileiro, reaccionaron mal e rexeitáronas como «ilexítimas».

Paradoxalmente, o que disto resultou, segundo a docente da UEM, non foi o orgullo de falar un portugués diferente, mozambicano -algunhas innovacións léxicas xa se perderon-, «senón unha vontade de "falar ben" o portugués, isto é, unha vontade de alcanzar unha converxencia coas regras do portugués europeo».

Os cambios máis significativos producidos no portugués de Mozambique "proveñen "naturalmente" da adquisición do portugués como lingua non materna, nun contexto en que os aprendices non teñen, en xeral, acceso á norma nativa europea, considerada o obxectivo, nin no seu contorno nin a través da instrución formal».

Un estudo realizado en 1999 sobre o discurso oral dos residentes en Maputo demostrou que «o $90 \%$ das desviacións [con respecto á norma europea do portugués] están relacionadas coa gramática, en contraste coas innovacións léxicas, que apenas representaban o 10\%», segundo Perpétua Gonçalves. 
Considerando que a meirande parte dos falantes de portugués non domina a norma europea, o que causa problemas na educación, estudosos e investigadores teñen debatido sobre a adopción dunha «norma mozambicana» para a lingua portuguesa, «baseada no discurso das persoas instruídas». O que acontece é que esta opción tamén formula problemas específicos, como indica Perpétua Gonçalves, porque a variante culta está moi lonxe de estabilizarse.

\section{Novo, urbano e falante do portugués}

O perfil do falante tipo da lingua portuguesa en Mozambique é un home novo que vive no medio urbano. Isto é así tanto para a reducida minoría que ten o portugués como lingua materna como para os que o teñen como segunda lingua -o $33 \%$ da poboación.

O $90 \%$ dos que teñen o portugués como lingua materna viven en centros urbanos. No medio rural «hai pouca motivación e poucas situacións nas que sexa necesario usar o portugués, por iso o número de falantes diminúe considerablemente», opina Perpétua Gonçalves.

Efectivamente, «o predominio do número de falantes de portugués nas cidades débese sobre todo a factores socioeconómicos, como o feito de que o coñecemento desta lingua sexa un requisito para acceder ao emprego», sostén a profesora.

Respecto aos que teñen o portugués como lingua materna, o censo de 1997 indica que a «maior proporción [...] sitúase no grupo de idade dos dez aos vinte anos, o 9\%", sinala o profesor Gregório Firmino.

Para Perpétua Gonçalves, o feito de que a porcentaxe de falantes que teñen o portugués como lingua materna se concentre nos grupos con idades de menos de trinta e cinco anos débese á data da independencia nacional, que constitúe «un marco importante na promoción social e consecuente prestixio desta lingua en Mozambique».

Entre as persoas de cincuenta ou máis anos censadas, «o coñecemento da lingua portuguesa é proporcionalmente insignificante», malia que este grupo de idade está composto por persoas que viviron máis tempo baixo o réxime colonial portugués.

É dicir, o Mozambique independente, ao facer da lingua portuguesa a «lingua oficial» do país, fixo máis - grazas ao seu uso obrigatorio na Administración 
e á política de escolarización masiva- pola súa difusión que o precedente goberno colonial portugués.

\section{A ortografía como símbolo}

A ortografía sempre foi o instrumento preferido na loita entre estas pulsións antagónicas. É comprensible: as convencións ortográficas obedecen máis ao lexislador e ao normalizador que aos feitos en si dunha lingua á deriva. Nas sociedades preocupadas pola alfabetización masiva, a ortografía é un requisito indispensable da escolarización. Nunha cultura en que a lingua escrita predomine sobre a falada, a ortografía é un privilexio de autoridade.

Así, acontece que a "pulsión unificadora» do portugués atinxiu o seu cénit co asinamento do Acordo Ortográfico luso-brasileiro de 1945, que aspiraba a reunificar, a través dunha ortografía común, as variantes nacionais en todas as súas manifestacións, incluídas as léxicas, sintácticas e fonolóxicas. Se lembramos que daquela tanto Brasil coma Portugal vivían baixo ditaduras, teremos menos dificultades para comprender o voluntarismo do tan irrealizable proxecto. Do mesmo xeito, o cénit da "pulsión separadora» alcanzouse coa recusa brasileira a adherirse ao devandito Acordo de 1945 tras un debate interno de gran vivacidade, como sempre acontece no eido ortográfico. Polo tanto, Brasil mantivo a súa ortografía propia, normativizada en 1943, mentres que Portugal e as colonias, hoxe Estados independentes, adoptaban a nova ortografía. Esta división do espazo da lingua portuguesa entre dous códigos ortográficos mantense vixente ata hoxe, pero está lonxe de ser unha novidade creada en 1945. O certo é que os desentendementos entre Portugal e Brasil por mor da ortografía tiñan, xa daquela, unha historia bastante longa e que merece contarse só resumidamente (Castro et al., 1987).

Na segunda metade do século XIX xurdiron en Portugal as primeiras propostas de reforma ortográfica, dirixidas a substituír diversas solucións etimoloxizantes por unha escrita simplificada e de representación fónica. O pioneiro foi J. Barboza Leão, pero os principais adeptos da ortografía fónica foron Carolina Michaëlis de Vasconcelos, que a usou na súa edición do Cancioneiro da Ajuda (Halle, 1904), e A. R. Gonçalves Viana, que tamén ese ano publicou Ortografia Nacional. Simplificação e Unificação Sistemática das Orto- 
grafias Portuguesas. A Academia non apoiou estas iniciativas particulares. Pola súa parte, a Academia Brasileira de Letras aprobou en 1907 unha ortografía que difire nalgúns puntos da de Gonçalves Viana. Instaurada a República en Portugal en 1910, o goberno encomendoulle a unha comisión de filólogos -non á Academia- a elaboración dunha ortografía, que acabou por ser unha versión atenuada das propostas de Gonçalves Viana, relator da comisión, conservando grafías xustificadas pola etimoloxía e polo seu uso xunto ás foneticamente motivadas. Unha vez aprobada como ortografía oficial en 1911, esta causou descontento en Brasil por tratarse dunha iniciativa unilateral. Iníciase daquela unha longa serie de encontros e desencontros das dúas academias, que en 1931 chegaron a un acordo que admitiu a posibilidade de que, en certos casos, existisen grafías distintas en ambos os dous países, pero este acordo non se aplicou moito tempo en ningún deles. Os dous gobernos asinan un Convenio Ortográfico en 1943, que ratifica o acordo de 1931. En 1945 celébrase unha Conferencia Interacadémica que aproba un acordo novo e diferente. Este é o acordo adoptado en Portugal ata o de agora, mentres que Brasil o rexeita por ser demasiado lusitanizante, manténdose fiel ao de 1943. Logo veu un longo intervalo, só interrompido en 1971 por un acordo mínimo sobre acentuación, que Portugal cumpriu e Brasil non. A entrada en escena en 1975 dos novos países de lingua oficial portuguesa, despois da descolonización, non alterou o estado das cousas, xa que en todos estes países se mantivo o uso da ortografía de 1945, común a Portugal. En 1985 reúnense de novo as dúas academias, agora con representantes dos demais países, e aproban unha ortografía marcadamente unificadora, moi innovadora e con algunhas deficiencias técnicas, que a opinión pública rexeitou clamorosamente en Portugal por «abrasileirada». A continuación viñeron dúas novas versións, a última delas aprobada en 1990 polas academias e polos gobernos. Corrixidas as imperfeccións e abandonadas as pretensións unificadoras, esta versión baséase nun principio de flexibilidade que establece grafías duplas para os casos de irreversible diverxencia morfofonolóxica. Este principio, proxectado a un futuro caracterizado pola existencia de tres ou catro variantes nacionais, non poderá deixar de admitir unha multiplicidade de grafías, mesmo rexionais, e permite preguntar que papel terá o prefixo «orto» nas grafías autorizadas. 
As principais innovacións do acordo de 1990 déronse en catro ámbitos:

- Consoantes mudas: consérvanse cando se pronuncian en todo o ámbito xeográfico da lingua portuguesa, como en «ficção», "pacto», "adepto», «núpcias»; e suprímense cando non se pronuncian en ningunha das normas cultas, como en "ação», «afetivo", "direção», «adoção", «ótimo»; teñen dupla grafía nos casos de pronuncia dupla, como «facto» ou «receção», en Portugal, fronte a «fato» e «recepção», en Brasil.

- Acentuación gráfica: teñen dupla grafía as vogais seguidas de «m» e de «n», nas proparoxítonas e paroxítonas, como «cómodo», «efémero», «fenómeno», «génio» ou «ténis», en Portugal, fronte a «cômodo», «efêmero», «fenômeno", "gênio" ou "tênis», en Brasil, así como as vogais finais nas oxítonas, como «bebé» ou "cocó», en Portugal, fronte a «bebê» ou "cocô», en Brasil.

- Uso do trazo: redúcese entre un prefixo rematado en vogal e unha palabra que comeza por «r» ou «S», e o trazo é substituído pola duplicación da consoante, como en «contrarregra» ou «infrassom»; e deixa de usarse na flexión de «há de» e "hão de».

- Alfabeto: pasa a incluír tres novas letras: «k», «W» e «y».

Esta ortografía de 1990, malia ser aprobada por todos os países, non foi aplicada en ningún deles. Moi recentemente, Brasil manifestou o seu desexo de resucitala co apoio de Cabo Verde. Abandonouse o requisito anterior, e absolutamente lóxico, de que a entrada en vigor dunha ortografía con vocación de «única» había de ser aprobada unanimemente polos países de lingua portuguesa; agora abonda coa sinatura de tres países. En 2007, o goberno portugués prepárase para converterse no terceiro país signatario. Con todo, consciente de que o resultado non sería a aplicación dunha ortografía única para o portugués, senón o mantemento de dúas - Brasil, Portugal e Cabo Verde por unha banda, e os demais países pola outra-, está prevista unha moratoria de dez anos antes da entrada en vigor definitiva da nova ortografía. Moitas cousas poden cambiar durante este tempo, entre elas os gobernos actuais. 


\section{A situación actual (de marzo a maio de 2008)}

Aprobación por parte de Portugal do acordo de 1990. Relacións con Brasil e África. Reaccións isolacionistas. Perspectivas de aplicación do acordo: oficialización de subnormas diverxentes, abandono das esperanzas reunificadoras.

\section{RESPOSTAS LINGÜÍSTICAS}

\section{Portugués europeo/portugués brasileiro (2000)}

E que din os lingüistas sobre a unidade da lingua portuguesa? Como no poema de Pessoa -que, non o esquezamos, era lingüista de fin de semana-, prefiren crer na variedade da lingua portuguesa. Ademais, os considerables avances que a lingüística do portugués experimentou nas últimas décadas serviron para enraizar a convicción de que existen divisións suficientes nas estruturas gramaticais entre o portugués de Portugal e o de Brasil para que se poida falar de «gramáticas ou linguas internas» diferentes, na terminoloxía de Charlotte Galves (1998). Esta constatación, derivada principalmente da análise da sintaxe, non é máis que corroborada polas análises levadas a cabo a outros niveis, como o fonolóxico ou o léxico. E o historiador da lingua non atopa motivos para que a lingua portuguesa, repartida por territorios descontinuos habitados por sociedades illadas unhas das outras, escape a unha fragmentación que nin o latín puido evitar nas terras chás europeas.

Robert Burchfield dixo que, de aquí a un século, as linguas de Inglaterra e dos Estados Unidos serán tan diferentes entre si como o italiano e o francés o son hoxe en día ${ }^{1}$. Vindo do autor do Suplemento (1972-1987) do Oxford English Dictionary, que serve de columna vertebral da lingua inglesa, isto paréceme unha esaxeración. Pero esta idea non quedou solteira: non se dubidou en editar o propio $O E D$ en versións especiais para o inglés canadense ou para o australiano. E Tom McArthur acaba de dedicarlle un libro titulado The English Languages a ese "complexo chamado inglés [que] é enormemente diverso -pro-

\footnotetext{
${ }^{1}$ Citado por Randolph Quirk, 1985, p. 3.
} 
bablemente máis que calquera outra lingua o foi xamais- e que vai camiño de selo aínda máis no vindeiro século», o que suscita a cuestión de saber se o inglés pode considerarse unha familia de linguas, á imaxe das linguas románicas ${ }^{2}$. $\mathrm{O}$ pragmatismo anglosaxón é envexable: no canto de causas perdidas, como a lusofonía, ou de pesimismos ante a morte anunciada de linguas, transforman en obxecto de estudo científico, e en produto de exportación, o comportamento inelutable da súa lingua no espazo e no tempo.

Coido que é co inglés co que máis paga a pena comparar a situación do portugués. En ambos os dous casos, a antiga metrópole ten un peso mundial moi inferior ao da antiga colonia americana e non é entendida por esta como un modelo; alén disto, o estándar lingüístico europeo de ambas as dúas linguas está singularmente desprovisto de mecanismos que aseguren a súa aceptación do outro lado do Atlántico. O inglés británico confíalle ao dicionario Oxford a función normativa en materia léxica e ortográfica, á BBC a pronuncia e ás escolas públicas, transmisoras da tradición do século $\mathrm{XVII}^{3}$, todo o demais. O portugués europeo ten unha ortografía oficial, que desde 1911 tenta compartir sen éxito con Brasil, pero non dispón dun dicionario nin dunha pronuncia «acollida». Inglaterra non ten unha Academia; Portugal si, pero como se non a tivese; polo que en ambos os dous países lles corresponde ás universidades estudar a lingua e preocuparse polo seu comportamento.

A relación de Francia coas súas ex-colonias é moi distinta, xa que ningunha destas ten unha dimensión suficiente como para liberarse da rede da francofonía, que é, de feito, un instrumento do predominio francés. A codificación da lingua é forte e levada a cabo por institucións antigas e centralizadoras. A probabilidade de que abrochen varias «linguas francesas» polo mundo adiante é tan escasa como a de que o éuscaro, o bretón e o provenzal cheguen a obter en Francia un status de autonomía comparable ao das linguas nacionais en España. No tocante a este país, a Real Academia Española, cos seus exemplares dicionario, gramática e ortografía, apoiada nos tempos modernos polo Instituto Cervantes,

\footnotetext{
2 «...the complex called English' is immensely diverse - probably more diverse than any single language has ever been- and is likely to become even more so in the next century. This book [...] addresses the question of whether or not English can be considered a family of languages in its own right, like the Romance languages» (McArthur, 1998).

${ }^{3}$ Véxase Hock e Joseph, 1996, p. 197-202.
} 
soubo manter un papel influente no desenvolvemento mundial da lingua española. Queda por ver se o crecemento exponencial do español nos Estados Unidos escapará a esta influencia.

Como resultado destes modelos diferentes de relacións dentro dun mesmo complexo lingüístico internacional, as normas europeas son máis respectadas nos países non europeos onde a lingua oficial é a francesa ou a española que nos de lingua oficial inglesa ou portuguesa. Isto quere dicir que no complexo portugués, ao igual que no inglés, as "pulsións separadoras» teñen máis posibilidades de dar como resultado produtos lingüísticos que, se cadra non dentro dun século pero si seguramente antes da celebración dos mil anos de Brasil -ou dos cincocentos de Angola e Mozambique-, sexan considerados, dentro e fóra, como linguas autónomas, emparentadas xeneticamente, que permiten unha intercomprensión razoable, pero que pertencen a sociedades que só se relacionarán a través da cultura dos medios de comunicación; linguas baseadas en gramáticas distintas e coa súa variedade interna organizada arredor de normas estándar propias ${ }^{4}$, as cales lles serven tamén de cara externa.

Algúns dirán que este non é o futuro da lingua portuguesa, senón o seu presente. Só queda saber o tempo en que se desenvolverá un proceso cuxos resultados finais son seguros. Convén ter presente, con todo, que para recoñecer o xurdimento dunha nova lingua non abonda con que a súa estrutura gramatical sufrise distanciamentos tipolóxicos radicais pero só observables con microscopio, nin abonda con que os membros dunha sociedade crean que a súa lingua é única: algunhas tribos norteamericanas reservaban para si a categoría de seres humanos; algúns brasileiros, coméntanme, non saben que se fala portugués fóra de Brasil; en calquera aldea de Trás-os-Montes explicarannos que os pobos veciños non saben falar ben o portugués. Unha nova lingua precisa tanto de autorecoñecemento como dun comparativismo empírico que lle asegure o recoñecemento externo. Pode que os modernos fluxos de información permitan que esa concienciación se produza moi rapidamente, sen as habituais demoras de xera-

\footnotetext{
${ }^{4}$ Cando falo de estándar refírome, evidentemente, a unha norma escrita e oral común, resultado da emerxencia de dialectos -por exemplo de Londres, París, Toledo ou Lisboa-, de coinés -como o grego alexandrino ou o suahili- ou de linguas literarias -caso do alemán e do italiano- (Hock e Joseph, 1996, p. 331). O termo «norma culta» talvez non se adecúe á realidade das sociedades modernas, a non ser que se acepte un concepto de cultura con predominio da agrafía e do analfabetismo.
} 
cións ou séculos. Temo, incluso, que cambios súbitos da actitude colectiva estean ao alcance duns poucos políticos, televisións, famosos, algún intelectual moi influente, grupos de presión ben pensantes e outros guerrilleiros mediáticos. Tendo en conta esta enorme inestabilidade, o papel orientador dos lingüistas pode ser decisivo.

Vexamos, nun breve repaso historiográfico, cal é a postura dos lingüistas con respecto a este problema. A lingüística portuguesa e brasileira das últimas décadas tivo dificultades para recoñecer na lingua común aquela unidade que Paiva Boléo defendía, e mesmo se recoñecía implicitamente que non existía. Celso Cunha inspirouse en categorías de Coseriu para describir o portugués como un sistema lingüístico unitario que albergaba dúas variantes nacionais consideradas como normas cultas (Cunha, 1981, p. 15-18). Lindley Cintra engadiu unha terceira variante nacional en proceso de formación, o galego, corrixindo así posturas anteriores nas que este se adoitaba considerar como un simple grupo de dialectos do portugués ${ }^{5}$. E estes dous lingüistas uníronse para abrirlle as portas da súa gramática normativa á lingua dos escritores africanos, o que apunta na dirección de variantes nacionais por definir. En todo caso, o modelo de Cunha e Cintra, polo seu recoñecemento dunha unidade superior do idioma, inscribíase no paradigma unificador; ambos os dous asistiron ao inicio da lusofonía e parece que isto non lles desagradou.

Coido que, se coñecesen as ideas de Źarko Muljačić sobre a formación de linguas por distanciamento (Abstandsprache) e por elaboración (Ausbausprache $)^{6}$, que no noso contorno se comezaron a divulgar a través da bibliografía galega ${ }^{7}$, tanto Celso Cunha como Lindley Cintra as adoptarían sen maiores reservas, pasando así dunha actitude unificadora a unha separatista. De feito, aquelas ideas permiten ter unha visión cómoda do portugués como un diasistema que comezou por ser unha lingua distanciada do leonés e do castelán, os seus veciños no marco ibero-románico primitivo, e que probablemente non pasaría de ser iso se quedase confinada ao espazo europeo. En épocas e lugares diversos, ese diasistema desenvolveu estándares variados a través de procesos de elaboración

\footnotetext{
5 "Au-dessus des dialectes galiciens on reconnaît une "norme", encore en voie de fixation, norme qui, comme la brésilienne, s'éloigne de la portugaise sous plusieurs aspects» (Lindley Cintra, 1983, p. 211).

${ }^{6}$ Por exemplo, Źarko Muljačić, 1988, p. 286-305.

${ }^{7}$ Por exemplo, Francisco Fernández Rei, 1988, p. 79-107.
} 
como a xerarquización de dialectos arredor dun que sobresae por motivos non lingüísticos, a adherencia a unha lingua literaria e a unha sede de poder, a "xenofobia dirixida ${ }^{8}$, que pecha o estándar a algúns contactos e o mantén aberto a outros, etc.

Un estándar formado deste xeito constitúe unha lingua por elaboración. A primeira delas formouse nos arredores de Lisboa e dos dialectos meridionais a partir da crise lingüística do portugués medio, no século XV; dirixiuse contra o portugués antigo de raíz galega e miñota, serviu de instrumento para a literatura portuguesa -incluída a colonial- durante o período clásico, e tamén de metalinguaxe para a descrición e normativización do portugués, iniciada no Renacemento, e é hoxe aquilo que chamamos portugués europeo.

A segunda lingua por elaboración desenvolveuse en Brasil a partir do dialecto de Río de Xaneiro, a única cidade colonial que foi, fugazmente, capital dun Imperio europeo. A cronoloxía, as fontes de contacto e os contornos desa elaboración constitúen, se non me engano, unha das grandes ocupacións da actual lingüística do portugués. Non corro o risco de errar se dixese que consiste na elaboración dun estándar brasileiro que, máis ou menos conscientemente, se define por contraste co europeo. Dado que as linguas por elaboración poden pasar a ser linguas por distanciamento cando se producen rupturas de comunicación dentro do diasistema e cando se perde a conciencia de que as semellanzas son máis importantes que as diferenzas, existe a posibilidade de que o portugués brasileiro veña a ser, ou xa sexa, unha Abstandsprache. Pero atención: se as varias linguas portuguesas de elaboración se convertesen en linguas distanciadas, cesará a súa condición de internacionais. Así, por exemplo, Brasil tería unha gran lingua de consumo interno: unha lingua nacional falada por millóns e millóns de persoas, todas brasileiras, ao igual que o mandarín, que é falado por miles de millóns de persoas, todas chinesas. Non creo, con todo, que este escenario estea próximo: as actuais condicións sociais e culturais non son as apropiadas para isto, como tampouco as fragmentacións tipolóxicas da lingua interna saíron das paredes do laboratorio. Trátase, de calquera xeito, dunha situación sen parangón no ámbito románico e acompañala atentamente terá un enorme interese metodolóxico e conceptual.

${ }^{8}$ Źarko Muljačić, 1999, p. 19. 
Con respecto ao proceso de elaboración do portugués brasileiro contarei unha breve anécdota. Hai meses, para unha homenaxe á profesora Cleonice Berardinelli, tiven que analizar a lingua dos seus escritos; a miña intención era atopar pegadas da norma culta brasileira saídas das mans dunha grande especialista da literatura portuguesa. A medida que avanzaba nas miñas indagacións, hei de confesar que só atopaba marcas de lusitanidade no seu léxico e no seu estilo: por exemplo, abundaban os pronomes átonos, cunha frecuencia e colocación propias do portugués europeo. Cando cheguei a algúns textos de relatorios presentados en Brasil, e que foron publicados sen revisión dela, foi cando atopei casos de posposición como «Brás também se admira de ouvi-lo» ou «que, por fim, mostraram-se eficientes», casos reveladores de que a lingua escrita de Berardinelli ten dúas normas, unha para o consumo oral nacional e outra para a lectura universal. Temos que chamarlles a ambas as dúas norma culta, pero a segunda é sen dúbida a norma culta do portugués europeo, que Cleonice cultiva como poucos; a primeira, obtida «sen revisións», é a que lle correspondería máis propiamente á norma culta do portugués brasileiro. Esta lingua de escritores é o mesmo que o estándar brasileiro? Non debería buscarse este a outras altitudes diastráticas, se cadra máis próximas á terra?

A terceira lingua por elaboración é o galego, que sente a necesidade de definirse fronte ao castelán -do que xa era unha Abstandsprache- e ao portugués, a cuxo diasistema pertence, como evidencia o continuum dialectal que vai da Coruña a Faro. A esperanza reintegracionista é a versión galega da lusofonía e terá o mesmo destino que esta. Ao tratarse dun proceso dos nosos días, a elaboración galega é na que os lingüistas desempeñan un papel máis importante, quer no seu acompañamento e descrición, quer no planeamento; a isto contribúe tamén o feito de que en Galicia existe un amplo consenso entre os lingüistas, e entre estes e as institucións, no tocante aos problemas e ás súas solucións.

A cuarta lingua por elaboración é, con toda probabilidade, o portugués mozambicano, que tamén conta xa cun puñado de valentes lingüistas á espreita, e a lóxica impón que tamén acabe por haber un portugués angolano. Pero teremos que agardar para ver se isto acontece.

Resultaría difícil compatibilizar co modelo de Celso Cunha e Lindley Cintra a chegada das lingüísticas teórica e dialectal, as cales, en Brasil, converxeron rapidamente no que respecta á identificación das características privativas brasileiras 
da lingua, con resultados moi relevantes que hoxe estamos en condicións de valorar. A chegada da lingüística moderna a Portugal foi diferente: a gramática xenerativa entrou pola fonoloxía, mentres que a sociolingüística nunca chegou a implantarse. Por isto, os primeiros embates déronse en solo brasileiro e, a causa disto e do programa, pode que asumisen algún cariz de querela de lingüística nova versus lingüística vella, e non sei se de lingüística brasileira versus lingüística portuguesa. Son deliberadamente impreciso ao referirme a este período do pasado recente, non por diplomacia ${ }^{9}$, senón porque considero que este merece un tratamento historiográfico completo, independente e informado, que non estou en condicións de tentar. Sería ideal un tratamento segundo o modelo da historiografía da lingüística proposto por E. F. K. Koerner, que incorpora na análise da produción científica dunha época a propia materia da investigación, os compromisos e supostos metodolóxicos, teóricos e ideolóxicos dos científicos, as tendencias multidisciplinarias dominantes e, de forma xeral, o «clima de opinión» da época (Koerner, 1995, p. 7-16).

A dispersión do portugués en varias linguas non precisa ser acompañada polo divorcio dos seus lingüistas. Pola contra, ese "portugués plurilingüe» reclama unha cada vez maior consonancia e colaboración entre os científicos dos diversos países e, como é natural aínda que non automático, o mantemento do portugués como metalingua da súa actividade. Por iso, unha historiografía contextualizadora pode ser moi útil para que se entenda non só o que din os lingüistas, senón tamén o motivo polo que o din.

Non é certo que aquilo que vemos é o que vemos no sitio onde estamos? Un bo exemplo disto témolo en como o espazo portugués é considerado polos xeógrafos e os dialectólogos (Mattoso, 1998, p. 45-46). O xeógrafo Amorim Girão elaborou un mapa de Portugal con tres grandes rexións: Norte, Centro e Sur. O seu colega Orlando Ribeiro distinguiu tres Portugais, un do Norte interior, un do Norte atlántico e un do Sur mediterráneo, o que dá como resultado un Norte e un Sur. Paiva Boléo distribuía os dialectos portugueses en tres grandes áreas,

\footnotetext{
${ }^{9}$ Para diplomacia basta a de Ataliba T. de Castilho, que describiu así este período: «Durante os anos de 60 e parte de 70, historiadores da Linguística Brasileira destacaram nosso apego às questóes teóricas e metodológicas, com prejuízo da apresentaçao dos fatos linguísticos propriamente ditos: Coseriu 1968, Dietrich 1980. Com a implantação dos Programas de Pós-graduação e o amadiurecimento dos meios científicos nacionais, alguns projectos colectivos de pesquisa e diversos trabalhos individuais mudaram esse estado de coisas» (Castilho, 1994, p. 869).
} 
máis ou menos coincidentes coas de Amorim Girão; ademais, consideraba que a poboación mozárabe da rexión Centro fora determinante na formación da lingua portuguesa, ao desprazarse cara ao val do Douro durante a Reconquista (Paiva Boléo e Silva, 1962, p. 85-112). Por último, Lindley Cintra só distinguía dúas grandes rexións dialectais, a Setentrional e a Meridional, e atribuíalles aos nativos de Entre-Douro-e-Minho e Galicia a autoría da nosa lingua (Lindley Cintra, 1971, p. 81-116). Pois ben, Girão e Boléo eran os únicos para os que estaba clara a individualidade dunha rexión central do país, correspondente ás Beiras: ambos os dous vivían e ensinaban en Coimbra. Ribeiro e Cintra, que non enxergaban esa individualidade intermedia, eran de Lisboa. Quizais isto é unha coincidencia.

\section{Aínda portugués europeo/portugués brasileiro (2007)}

Outros trazos de carácter case sempre sintáctico, ademais, obviamente, dos léxicos, son hoxe determinantes para distinguir as variantes europea e brasileira (Teyssier, 2003; e Mateus et al., 2003, p. 45-51). Estes alimentan un debate no ámbito tipolóxico que ocupa en boa medida os estudos actuais da lingüística do portugués: as diferentes solucións observadas en Portugal e Brasil inscríbense no ámbito normal da variación sistemática. Daquela, podemos considerar, dentro do paradigma de Coseriu, que ambos os dous países teñen normas diferenciadas dentro dun único sistema -como Cintra e Celso Cunha defendían ao falaren de «variantes nacionais» (Cunha, 1981, p. 11-36)-, ou, pola contra, debemos comezar a pensar que hai «dúas gramáticas», eufemismo técnico que oculta o radicalismo de «dúas linguas»?

Neste contexto de debate, resulta interesante observar o comportamento das vogais átonas, que no portugués europeo son cada vez menos audibles. A variante brasileira caracterízase pola conservación do sistema portugués clásico -nê-cê-ssá-ri-ô, có-mô-dô-, mentres que en Portugal as vogais átonas sufriron pechamento -à $>$ â- e elevación a schwa - $\hat{\mathrm{e}}>\partial$, ô $>\mathrm{u}>\partial-$ ou mesmo desapareceron -nə -[cə]ssá-riu > nsá-riu, ou có-mu-du > có-mə-du > cóm-du-. Neste comportamento vocálico atópanse dúas utilidades xerais: por unha banda, compróbase que o portugués de Portugal pode ser máis innovador que o de Brasil, en contra dunha idea moi común, segundo a cal a variante europea presenta unha 
maior estabilidade; por outra banda, dedúcese que a evolución do portugués en África talvez non siga o modelo brasileiro, como defende outra idea común, segundo a cal as antigas colonias portuguesas se comportarán lingüisticamente de modo paralelo e, xa que logo, terán máis afinidades entre si que coa antiga metrópole. En efecto, cando a vogal átona é seguida de «l», o portugués europeo, excepcionalmente, non a eleva e conserva a vogal, ao igual que o brasileiro -álmeidâ e non âlmeidâ, vóltár e non vultár. Pero o portugués africano distínguese de ambos os dous por ir alén da regra xeral da elevación -âlmeidâ, vultár-, sendo neste aspecto máis innovador que as outras dúas variantes. Visto con perspectiva, daquela, é posible admitir que novas gramáticas se desenvolvan en África, distintas da portuguesa e da brasileira e, se cadra, diferentes entre Angola e Mozambique.

\section{Portugués europeo/galego}

Segundo Maria Antónia Coelho da Mota (2001, p. 103-115):

Quando falamos de «gramática do PE1 (fronteiriço)» estamos, assim, a referir-nos a uma gramática que coexiste com outras gramáticas, no espaço geográfico portugués, e que, com elas, forma um continuum geográfico. Em PEl, há muita matéria para contrastar com o Galego. Por razóes de limitaçao deste comentário, centrar-me-ei numa questáo particular -a Ligaçáo entre verbo e pronome enclítico e entre verbo e artigo-, mas exemplificaria, apenas com dois casos, outros tipos de semelhanças e de diferenças [...]. Conclui-se que as variantes verdadeiramente caracterizadoras de PE1, no sentido em que nito sito partilhadas por outras variedades do $\mathrm{PB}$, pelo menos padrito e meridionais, não tém equivalentes sistemáticos com GAl. Se tomarmos, no entanto, em consideração as variantes que, em PEI, são comuns ao padrão, temos mais pontos de contacto com o GAl: dito de outra forma, há muitos pontos de contacto entre GAl e o chamado PE padrão, que talvez seja a variedade que, em português, reúne os traços comuns a todas as variedades.

\section{A nosa lingua}

Pero, se estamos de acordo con Eduardo Prado Coelho en que unha lingua é «o lugar onde falamos sempre de dentro, tal como o corpo que nos é inerente e que 
nunca conseguimos ver como mero objecto exterior a nós» (1992, p. 17), daquela non teremos dificultades para identificar como «nós» a todos cantos se sintan como na casa ao falar portugués.

Certo é que non todos teremos un pasaporte da mesma cor; algúns de nós cruzamos as fronteiras de Europa con máis facilidade que outros; algúns de nós non coñecemos, non imaxinamos sequera, como é a terra dos outros e, cando a coñecemos, sentímola como terra estranxeira. Con todo, e sen sabelo, todos temos en común que a lingua que falamos como nosa lle semella, a quen a ve desde fóra, sempre a mesma; e todos sentimos indignación se o espectador externo sinala, esaxerando o comentario, que a diferenza entre o portugués e o español non é moi grande ${ }^{10}$. E isto porque temos en común sentimentos de propiedade e de identidade separadora, esa que di o que non somos e o que non ten que ver connosco.

Pero, no que atangue á identidade conxuntiva, aquela que faría que todos os falantes do portugués se sentisen unidos, as cousas complícanse. Brasileiros, portugueses e africanos pertencemos a nacións diferentes, de Estados distintos, de continentes diversos e non lamentamos que sexa así. Polo xeral, non sentimos a necesidade de loitar contra esa condición da nosa existencia e, no que se refire á lingua, non sentimos que o feito de térmola en común e de usármola entre nós para entendérmonos e, non o esquezamos, para os desentendementos, haxa de ter consecuencias niveladoras, quer no tocante á lingua, quer ás nosas relacións. Non é preciso que un poeta diga que entre os falantes da lingua tamén existe variación.

10 «By most objective standards, it is almost only the phonological [e orthográficas] differences that set the two languages [español e portugués] off from each other» (Posner, 1996, p. 209). 


\section{BIBLIOGRAFÍA}

Castilho, A. T. DE: «O português do Brasil», en R. Lorenzo (ed.): Actas do XIX Congreso Int. de Linguistica e Filoloxía Románica VI, A Coruña, 1994.

CAStro, I. et al:: A Demanda da Ortografia Portuguesa, Lisboa, 1987.

Coelho Da MотA, M. A.: «O portugués na fronteira com o galego», Revista de Filología Románica, vol. 18 (2001), p. 103-115.

CunHA, C.: «Política e cultura do idioma», en Língua, nação e alienação, Rio de Janeiro, 1981.

FERNÁNDEZ ReI, F.: «Posición do galego entre as linguas románicas», Verba, 15 (1988), p. 79-107.

GALVES, C.: "A gramática do português brasileiro", Linguas e Instrumentos Criticos, Campinas, n.o 1 (xaneiro-xuño, 1998).

Hock, H. H. e B. D. JosepH: Language History, Language Change and Language Relationship, Berlín-Nova York, 1996.

Koerner, E. F. K.: «Historiography of Linguistics», en Koerner e AsHer (ed.): Concise History of the Language Sciences, Oxford, 1995, p. 7-16.

Lindley Cintra, F. L.: «Nova Proposta de Classificação dos Dialectos Galego-Portugueses», Boletim de Filologia, XXII (1971), p. 81-116.

Lindley CinTRA, F. L.: «Présence et problématique actuelle de la langue portugaise dans le monde», Arquivos do Centro Cultural Português, París, XIX, 1983.

LOURENÇO, E.: A Nau de Ícaro, Lisboa, 1999.

Mateus, M. H. et al:: Gramática da Lingua Portuguesa, 5. ${ }^{\text {a }}$ ed., Lisboa, 2003.

Mattoso, J.: A Identidade Nacional, Lisboa, 1998.

MCArThur, T.: The English Languages. Cambridge, III, 1998.

MuljAČIĆ, Ź.: «Norma e standard», en G. Holtus, M. METZELTIN e C. SCHMITT (ed.): Lexikon der Romanistischen Linguistik, Tübingen, 1988, p. 286-305.

MULJAČIIĆ, Ź.: «Estandardización de linguas románicas baixo presión: unha proposta tipolóxica», en FERnÁndez Rei e A. Santamarina (ed.): Estudios de Sociolingüistica Románica, Santiago de Compostela, 1999.

Ostler, N. (2006): Empires of the Word. A Language History of the World, Nova York, 2006.

Paiva Boléo, M. e M. H. S. Silva: «O Mapa dos Dialectos e Falares de Portugal Continental», en Actas do IX Congresso Int. de Linguística Românica, Lisboa, III, 1962, p. 85-112.

Paiva Boléo, M.: $O$ «espaço linguístico» português, Coimbra, 1968.

POSNER, R.: The Romance Languages, Cambridge, 1996.

Prado CoelHo, E.: «O português, língua de comunicação internacional», RILP, 7 (1992).

QUIRK, R.: English in the World, Cambridge, 1985.

Rocha Trindade, M. B.: "O espaço da Lusofonia: migrações e diálogo intercultural», Discursos, 15 (1998).

Teyssier, P.: Manual de Lingua Portuguesa (Portugal-Brasil), Coimbra, 2003. 